JOURNAL OF LATIN AMERICAN STUDIES 1975

L.A.S. $-a^{*}$ 


\section{JOURNAL OF}

LATIN AMERICAN STUDIES

VOLUME 71975

\section{Editors:}

HAROLD BLAKEMORE

CLIFFORD T. SMITH

Editorial Board:
A. R. M. CA R R
P. FL YNN
R. A. HUMPHREYS
J. LYNCH
J. STREET

CAMBRIDGE UNIVERSITY PRESS

1975

CAMBRIDGE · LONDON · NEW YORK 
Published by the Syndics of the Cambridge University Press The Pitt Building, Trumpington Street, Cambridge, CB2 1RP

Bentley House, 200 Euston Road, London, NW1 2DB

32 East 57th Street, New York, N.Y. 10022, U.S.A.

(C) Cambridge University Press 1975

Printed in Great Britain by The Eastern Press Ltd, London and Reading 


\section{Articles}

ANNA, Timothy E.: The Peruvian Declaration of Independence: Freedom by Coercion

BROMLEY, Rosemary D. F. and BROMLEY, R. J.: The Debate on Sunday Markets in Nineteenth-Century Ecuador

CLAYTON, L. A.: Trade and Navigation in the Seventeenth-Century Viceroyalty of Peru

EASTWOOD, D. A.: Observations on the Relationship between Intrarural Migration and Achievement Motivation in Mérida State, Venezuela

KLEIN, Herbert S.: Hacienda and Free Community in Eighteenth Century Alto Peru: A Demographic Study of the Aymara Population of the Districts of Chulumani and Pacajes in 1786

MORTON, F. W. O.: The Military and Society in Bahia, I800-1821

NUNN, Frederick M.: New Thoughts on Military Intervention in Latin American Politics: The Chilean Case, 1973

PYNE, Peter: The Politics of Instability in Ecuador: The Overthrow of the President, 1961

REDCLIFT, Michael: Peasants and Revolutionaries: Some Critical Comments

SINGELMANN, Peter: Political Structure and Social Banditry in Northeast Brazil

WOLL, Allen L.: For God or Country: History Textbooks and the Secularization of Chilean Society, 1840-1890

WRIGHT, Thomas C.: Agriculture and Protectionism in Chile, I8801930 


\section{Reviews}

Adamson, Alan H.: Sugar Without Slaves: The Political Economy of

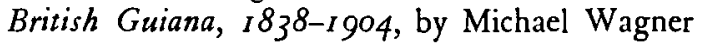

Alexander, Robert J. (ed.): Aprismo: The Ideas and Doctrines of Victor Raúl Haya de la Torre, by Rory Miller

Amlr, Shimeon: Israel's Development Cooperation with Africa, Asia and Latin America, by Edy Kaufman

Atrins, G. Pope and Wilson, Larman C.: The United States and the Trujillo Regime, by Gordon Connell-Smith

Baines, John M.: Revolution in Peru: Mariátegui and the Myth, by Jesus Chavarria

Balán, Jorge, Browning, Harley L. and Jelin, Elizabeth: Men in a Developing Society: Geographic and Social Mobility in Monterrey, Mexico, by Alan Gilbert

Bastide, Roger: African Civilisations in the New World, by Colin Henfrey

$18 \mathrm{I}$

Bingham, Marie B.: A Catalogue of the Yucatan Collection on Microfilm in the University of Alabama Libraries, by Bernard Naylor

Blakemore, Harold: British Nitrates and Chilean Politics, 1886I896 : Balmaceda and North, by D. C. M. Platt

Blanco, Hugo: Land or Death, by Michael Redclift

Bonachea, Ramon L. and San Martin, Marta: The Cuban Insurrection, 1952-1959, by Lynn Darrell Bender

Bridenbaugh, Carl and Roberta: No Peace Beyond the Line. The English in the Caribbean, by D. B. Quinn

Bruneau, Thomas C.: The Political Transformation of the Brazilian Catholic Church, by Ken Medhurst

Calvert, Peter: Mexico, by Brian Hamnett

Campbell, Gordon: Brazil Struggles for Development, by J. P. Dickenson

Cancian, Frank: Change and Uncertainty in a Peasant Economy, by Michael Redclift

Cannon, Mark W., Fosler, R. Scott and Witherspoon, Robert: Urban Government for Valencia, Venezuela, by Alan Gilbert

Carmack, Robert M.: Quichean Civilization: The Ethnohistoric, Ethnographic, and Archaeological Sources, by Warwick Bray

Chang-Rodríguez, Eugenio (ed.): The Lingering Crisis : A Case Study of the Dominican Republic, by Gordon Connell-Smith 
Chilcote, Ronald H.: The Brazilian Communist Party : Conflict and Integration 1922-1972, by Alan Angell

Clausner, Marlin D.: Rural Santo Domingo: Settled, Unsettled and Resettled, by Michael Redclift

Clissold, Stephen: The Saints of South America, by C. R. Boxer

Collier, Jane Fishburn: Law and Social Change in Zinacantan, by Peter Rivière

Cóndova, Arnoldo: La ideologia de la Revolución Mexicana : La formación del nuevo régimen, by D. L. Raby

Cortés, Hernan; Pagden, A. R. (trans. and ed.): Letters from Mexico, by C. A. Jones

Cortés Conde, Roberto; Talbot, Tony (trans.): The First Stages of Modernization in Spanish America, by Rory Miller

Davis, Harold Eugene: Latin American Thought-a historical introduction, by Stephen Clissold

de Galíndez, Jesús; Fitzgibbon, Russel H. (ed.): The Era of Trujillo, by Gordon Connell-Smith

Eisenberg, Peter L.: The Sugar Industry in Pernambuco 1840-1910: Modernization Without Change, by J. H. Galloway

Evenson, Norma: Two Brazilian Capitals, by Geoffrey Jellicoe

Fagen, Richard R. and Tuony, William S.: Politics and Privilege in a Mexican City, by Peter Calvert

Fals Borda, Orlando: Cooperatives and Rural Development in Latin America, by Michael Redclift

Ferns, Henry Stanley: The Argentine Republic 1516-1971, by Roger Gravil

Foner, Philip S.: The Spanish-Cuban-American War and the Birth of American Imperialism, by Joseph Smith

Gerassi, John (ed.): Camilo Torres: Revolutionary Priest, by Michael Redclift

Gutiérrez, Carlos María; Edwards, Richard E. (trans.): The Dominican Republic: Rebellion and Repression, by Gordon Connell-Smith

Halper, Stefan A. and Sterling, John R. (eds): Latin America: The Dynamics of Social Change, by Tessa Cubitt

Hamshere, Cyril: The British in the Caribbean, by D. B. Quinn

Hardoy, Jorge E.: Pre-Columbian Cities, by George Bankes

Hawrins, Carroll: Two Democratic Labor Leaders in Conflict, by Alan Angell

Heath, Shirley Brice: Telling Tongues. Languages Policy in Mexico, Colony to Nation, by John Rutherford

Herman, Donald L. (ed.): The Communist Tide in Latın America, by Alan Angell 
Hill, Larry D.: Emissaries to a Revolution : President Wilson's Executive Agents in Mexico, by Peter Calvert

Huizer, Gerrit: Peasant Rebellion in Latin America, by Michael Redclift

Klarén, Peter F.: Modernization, Dislocation, and Aprismo: Origins of the Peruvian Aprista Party, I870-1932, by Rory Miller

LeAcock, Seth and Ruth: Spirits of the Deep: a Study of an AfroBrazilian Cult, by Colin Henfrey

Levine, Daniel H., Conflict and Political Change in Venezuela, by D. A. G. Waddell

L'Histoire Quantitative du Brésil de I80o à $193^{\circ}$, by Thomas E. Skidmore

Liss, Sheldon B.: The Canal: Aspects of United States-Panamanian Relations, by Gordon Connell-Smith

I9I

Maxwell, Kenneth R.: Conflicts and Conspiracies : Brazil and Portugal $175^{0-1} 808$, by Jaime Reis

Moreno, José A.: Barrios in Arms : Revolution in Santo Domingo, by Gordon Connell-Smith

Moss, Robert: Chile's Marxist Experiment, by Juan Ricardo Couyoumdjian

Murmis, Miguel and Portantiero, Juan Carlos: Estudios sobre los origenes del peronismo 1, by Roger Gravil

Nelson, Lowry: Cuba: the Measure of a Revolution, by Francis Lambert

Ortı, Sutti R.: Uncertainties in Peasant Farming, A Colombian Case, by Michael Redclift

Panata, Marta, Lesser, Ricardo and Skupch, Pedro: Estudios sobre los orígenes del peronismo 2, by Roger Gravil

Payne, Stanley G., A History of Spain and Portugal, by Henry Kamen

Peralta Ramos, Mónica: Etapas de acumulación y alianzas de clases en la Argentina, 1930-1970, by David Rock

Petras, James and Merino, Hugo Zemelman: Peasants in Revolt: A Chilean Case Study, 1965-71, by Michael Redclift

Pinelo, Adalberto J.: The Multinational Corporation as a Force in Latin American Politics: A Case Study of the International Petroleum Company in Peru, by Edith Penrose

Quirk, Robert E.: The Mexican Revolution and the Catholic Church, I9I0-1929, by D. L. Raby

Ramsey, John: Spain: The Rise of the First World Power, by Henry Kamen

Randall, R. W.: Real del Monte. A British Mining Venture in Mexico, by Michael P. Costeloe 
Ronfeldt, David: Atencingo, The Politics of Agrarian Struggle in a Mexican Ejido, by Michael Redclift

Ross, James E.: Cooperative Rural Electrification : Case Studies of Pilot Projects in Latin America, by R. J. Bromley

Russell-Wood, A. J. R. (ed.): From Colony to Nation : Essays on the Independence of Brazil, by C. R. Boxer

SARIola, Sakari: Power and Resistance. The Colonial Heritage in Latin America, by Henry Kamen

Sater, William F.: The Heroic Image in Chile: Arturo Prat, Secular Saint, by Arnold J. Bauer

Silver, Daniel B.: Illness and Shamanistic Curing in Zinacantan : an Ethnomedical Analysis, by Peter Rivière

Siskind, Janet: To Hunt in the Morning, by Warwick Bray

SMITH, Peter H.: Argentina and the failure of democracy: conflict among political elites, 1904-1955, by David Rock

Strickon, Arnold and Greenfield, Sidney M. (eds): Structure and Process in Latin America. Patronage, Clientage and Power Systems, by John Stuart MacDonald

Suchlicki, Jaime (ed.): Cuba, Castro, and Revolution, by Francis Lambert

Walker, Malcolm T.: Politics and the Power Structure. A Rural Community in the Dominican Republic, by Malcolm Deas

WeEdLe, Robert S.: Wilderness Manhunt. The Spanish Search for La Salle, by D. B. Quinn

Wiarda, Howard J.: Dictatorship and Development: The Methods of Control in Trujillo's Dominican Republic, by Gordon ConnellSmith

Zeituin, M. (ed.): Revolutionary Writings : Father Camilo Torres, by Michael Redclift 


\section{THIRD WORLD POLITICS}

\section{PEASANTS, POLITICS, AND REVOLUTION}

Pressures Toward Political and Social Change in the Third World

JOEL S. MIGDAL

Drawing on various sources, the author shows that material incentives rather than ideological fervor induce Third World peasant communities to leave their villages for political activity or sustained revolution. $\$ 15.00$

\section{MULTINATIONAL CORPORATIONS AND THE} POLITICS OF DEPENDENCE

\section{Copper in Chile}

THEODORE H. MORAN

Using the Chilean copper industry to study the relations between multinational corporations and their host countries in the Third World, the author describes the reaction against dependencia. Written under the auspices of the Center for International Affairs, Harvard University. \$12.50

Write for our new Political Science Catalogue.

PRINCETON UNIVERSITY PRESS

Princeton, New Jersey 08540

\section{MEXICO UNDER SPAIN, 1521-1556}

\section{Society and the Origins of Nationality Peggy K. Liss}

In this broadly conceived overview, Peggy K. Liss provides the first comprehensive study of the origins

of a separate Mexican identity within the Spanish empire in the first half of the sixteenth century. Her work is at once a fresh narrative history of the first generation after the Spanise conquest and an examination of the formative years of Mexican society. 1975240 pages Cloth $\$ 12.50$

\section{The University of Chicago Press Chicago 60637}




\section{Race, Class and Politics in Colonial Mexico 1610-1670}

J. I. Israel

The social structure of Spanish Mexico in the seventeenth century presents a complex picture of different racial groups, and reflects the rivalry of two distinct European élites for political and economic domination. This book investigates the tensions at work in this multiracial social structure and their effect on the political and social development of the viceroyalty. $£ 8$ Oxford Historical Monographs

\section{Empires to Nations}

\section{Expansion in America 1713-1824}

\section{Max Savelle}

The main themes of this volume are the evolution of the English, French, Spanish, Portuguese, and Dutch empires in the New World into separate and distinct societies, and their differentiation from each other and from their mother countries. Out of the birth and growth of national self-consciousness there developed a nationalism and anti-colonialism which led to the movements for independence which began in the United States and finished with the independence of Brazil. Illustrated $£ 5.75$

\section{The Piaroa: A People of the Orinoco Basin}

\section{A Study in Kinship and Marriage}

\section{Joanna Overing Kaplan}

Ideally, a Piaroa marries within the multiple-family communal house into which he was born; but the mode of political achievement among the Piaroa is such that this ideological ordering is often disrupted in practice. This ethnographic account throws light on the peculiar problems of analysis presented by the tribal societies of South America. $\quad \mathfrak{f} 8.50$

\section{Black into White}

\section{Race and Nationality in Brazilian Thought}

\section{Thomas E. Skidmore}

This book examines the development of racial attitudes in Brazil and discusses them particularly in relation to her growing sense of national identity. Before abolition of slavery and the establishment of a republic late in the nineteenth century, Brazilian intellectuals had given little thought to the problem of race, but have shared pride in their nation's race politics ever since the 1930 s, when a positive approach to Brazil's multi-racial composition was encouraged. $£ 5 \cdot 75$

\section{Oxford University Press}




\section{haRper paperbacks}

\section{Stan Steiner}

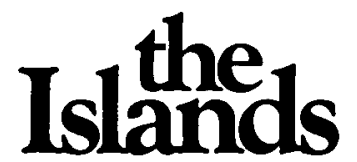

The Worlds of the Puerto Ricans

Photographs by Geno Rodriguez

"Earthy and informal, pungent with the flavor of the barrio, these vignettes of Puerto Rican life in the island and in New York provide a kind of curbstone sociology."

$$
\text { -Foreign Affairs }
$$

"One more step taken toward the dignity - and a better understanding - of my people." -PIRI THOMAS

\section{The New Indians}

"The subject is timely and complex; here it is given both unity and perspective. Stan Steiner is a wanderer, and he keeps a sharp eye on the land.... He has come to know better than most men the American landscape and the people who are native to it. He has lived among the tribes and has written well of them." -New York Times Book Review

CN/416 \$3.95

Also by Stan Steiner

LA RAZA

The Mexican Americans

$\mathrm{CN} / 203 \quad \$ 2.75$

For a complete

catalog, write

Harper $\Theta$ Row

Paperback Dept.

IOE. 53d SI., New York 10022 
DANIEL H. LEVINE

\section{CONFLICT AND POLITICAL CHANGE IN VENEZUELA}

Venezuela has had a long and bloody history of military dictatorship. Yet, since 1958, it has developed one of the few effective, competitive democracies in Latin America. To explain this transformation Daniel $H$. Levine analyzes the development of modern mass-based political parties with pervasive organisations and commanding strong loyalties; the changing structure and content of social and political conflict; and the gradual emergence of common norms governing political behaviour.

691075476

$\pm 7 \cdot 60$

FRANK D. MCCANN, Jr.

\section{THE BRAZILIAN-AMERICAN ALLIANCE IN WORLD WAR II, 1937-1945}

Getúlio Dornelles Vargas established his dictatorship in Brazil in 1937, and from 1938 to 1940 American diplomats and military planners were preoccupied with the possibility that Brazil might ally herself with Nazi Germany. Such an alliance would have made fortress America vulnerable and closed the South Atlantic to Allied shipping. Fortunately for America, Brazil eventually joined the Allies and American engineers turned Northeast Brazil into a vast springboard for supplies for the war fronts. Frank D. McCann has used previously inaccessible Brazilian archival material to discuss the events during the Vargas regime which brought about a close alliance between Brazil and the United States and resulted in Brazil's economic, political, and military dependence on her powerful North American ally.

$691056552 \quad £ 10.80$

\section{DANA GARDNER MUNRO}

\section{THE UNITED STATES AND THE CARIBBEAN REPUBLICS, 1921-1933}

Between 1921 and 1933, the United States moved from a policy of active intervention to a policy of noninterference in the internal political affairs of the Caribbean states. How the shift from the diplomacy of the Taft and Wilson administrations to the Good Neighbour policy of Franklin Roosevelt occurred is the subject of Dana Gardner Munro's book. The author draws on special records and on his personal experience as a member of the Latin American Division of the United States Department of State to piece together the history of the transition in diplomatic policy.

$691046239 \quad$ flO.20

\section{ABRAHAM F. LOWENTHAL, Editor THE PERUVIAN EXPERIMENT Continuity and Change Under Military Rule}

Peru's self-proclaimed " revolution"-surprisingly extensive reforms initiated by the military government-has aroused great interest all over Latin America and the Third World. This book is the first systematic and comprehensive attempt to appraise Peru's current experiment in both national and regional perspective. It compares recent innovative approaches to Peru's problems with the methods used by earlier regimes, providing original and stimulating interpretations of contemporary Peru from the viewpoints of political science, sociology, history, economics, and education.

$691075727 \quad £ 13.50$

$691100357 \quad £ 4.05$ Limited paper edition

PRINCETON UNIVERSITY PRESS

70 Great Russell Street, London WC1B 3BY. Tel.: 01-405 0182 


\section{R. DIAZ-GUERRERO \\ PSYCHOLOGY OF THE MEXICAN}

\section{Culture and Personality}

In his quest to understand and describe the behaviour of the Mexican, the distinguished Mexican psychologist R. Diaz-Guerrero combines a strong theoretical interest in the relationship of culture to personality with a pragmatic concern for methodology. This collection of essays is rooted both in studies of Mexican psychology as an independent phenomenon and in cross-cultural comparisons of Mexicans, Mexican-Americans, and Anglo-Americans.

$$
\begin{array}{llllll}
\text { Texas } & 292 & 77512 & 1 & 1975 & £ 5.50
\end{array}
$$

\section{WAYNE H. HOLTZMAN, ROGELIO DIAZ-GUERRERO, \& JON D. SWARTZ \\ PERSONALITY DEVELOPMENT IN TWO CULTURES}

\section{A Cross-Cultural Longitudinal Study of School Children in Mexico and the United States}

This book is the outcome of an extensive investigation of the different patterns of personality, cognitive, and perceptual development of school children in Mexico and the United States. It presents and analyses the results of the study, in which over eight hundred children in Mexico City and Austin, Texas were tested repeatedly over a six-year period under the supervision of highly respected Mexican and American psychologists.

Texas $292764251 \quad$ Forthcoming $\quad £ 9.00$ approx.

\section{J. RICHARD ANDREWS}

\section{INTRODUCTION TO CLASSICAL NAHUATL}

Classical Nahuatl was the language used by the Aztecs at the time of Cortes's conguest of Mexico and until near the end of the colonial period. Introduction to Classical Nahuatl is the first concerted, detailed application of modern linguistic analysis to Nahuatl and the most helpful guide available to the language's unusual features. The grammatical structures are presented in a systematic, stepby-step progression, designed for use either in self-instruction or in class study. The book is divided into four parts, dealing with basic verbal sentences, derived verbal sentences, nominal sentences, and the combinations of these simple sentences into complex and compound structures. A comprehensive vocabulary is included in the first volume, organised in such a way as to make its use a further part of the learning process. The accompanying workbook contains exercises that drill the principal points discussed in the grammar, supplementary reading passages, and a key.

$\begin{array}{llllll}\text { Texas } & 292 & 73804 & 8 & f 19 \cdot 75 \text { Text } & \text { Forthcoming }\end{array}$

\section{CHARLES H. HARRIS III}

\section{A MEXICAN FAMILY EMPIRE}

\section{The Latifundio of the Sánchez Navarros, 1765-1867}

Perhaps no other institution has had a more significant impact on Latin American history than the large landed estate-the hacienda. In Mexico, the latifundio, an estate usually composed of two or more haciendas, dominated the social and economic structure of the country for four hundred years. A Mexican Family Empire is a careful examination of the largest latifundio ever to have existed, not only in Mexico but also in all of Latin America-the latifundio of the Sánchez Navarros.

Texas $29275020 \times \quad$ Forthcoming $£ 9.00$ approx.

AMERICAN UNIVERSITY PUBLISHERS GROUP LTD.

70 Great Russell Street, London WC1B 3BY Tel: 01-405 0182 


\section{CONTEMPORARY MEXICO \\ Papers of the IV International Congress of Mexican History}

Edited by

James W. Wilkie, Michael C. Meyer, and Edna Monzón de Wilkie

This comprehensive volume offers a new and important interdisciplinary focus on Mexican history since 1910, and comprises the most up-to-date work yet available.

The editors have organized 45 papers by leading Mexicanists into a cohesive volume which treats the following topics: population, space, and migration since 1910; elites and masses; land reform; the roles of the Church and the military; official party politics; the Mexican economy and its role in Latin American; Mexican-U.S. relations; the Chicano and the Mexican; education and cultural life; periodization of contemporary Mexican history; and the present and likely future state of scholarship on these subjects. About half the papers are in Spanish. 800 pages $£ 13.75$

\section{NEGRO SLAVERY IN LATIN AMERICA}

\section{Rolando Mellafe}

This is the first general study of slavery in Latin America to be made available in English. It covers the period from the Conquest to abolition, describing conditions favorable to the introduction of slaves in various regions and the development, magnitude, and decline of the slave-holding colonies. Considerable attention is given to the slave trade: the transoceanic routes, sources of supply in Africa, numbers of people, and the system of marketing and distribution in Latin America. Spain never had effective control over this trade; the author discusses the reasons for this. He also analyzes the legal and social controls that evolved during the slave period and the transition from slavery to other forms of servile labor. The book includes a large bibliography.

240 pages $£ 6 \cdot 30$

\section{THE PEASANT MARKETING SYSTEM OF OAXACA, MEXICO}

\section{Ralph L. Beals}

This is the first study of peasant economics to deal with the totality of a marketing system. Most studies of peasant economics have centered on a single village or a single marketplace and have at most touched upon the larger marketing system or network only tangentially. The Oaxaca system consists of hundreds of villages and dozens of marketplaces serving nearly a million people and involving goods valued conservatively at more than a billion pesos annually. The Oaxaca system thus is the largest and one of the best preserved of a number of traditional peasant marketing systems existing in Mesoamerica.

420 pages $£ 11 \cdot 00$

\section{University of California Press}

\section{2-4 Brook Street, London W1}


CAMBRIDGE LATIN AMERICAN STUDIES 18 Politics, Economics and Society
in Argentina in the Revolutionary
Period

TULIO HALPERIN-DONGHI

A study of the birth of political life and the rise of a political leadership in the River Plate area during the struggle for independence from Spain. Professor Halperin's book, translated by Richard Southern, is set against the background of the economic uncertainty associated with independence.

£14.50 net

\section{CAMBRIDGE LATIN AMERICAN STUDIES 19 Politics in Argentina 1890-1930}

The Rise and Fall of Radicalism

\section{DAVID ROCK}

This study is concerned with the 40-year period before 1930, when Argentina experienced rapid economic and social growth broken only by the First World War.

f6.60 net

\section{CAMBRIDGE LATIN AMERICAN STUDIES 20}

\section{Studies in the Colonial History of Spanish America \\ MARIO GÓNGORA}

The seven essays in this study demonstrate the exceptional range of Professor Góngora's writing: they run from the eve of discovery and conquest of the Indies to the end of the Spanish Empire, and connect matters as seemingly distant as the place of the New World in Spanish utopian thought and the humble workings of the native labour system.

£6.50 net

CAMBRIDGE LATIN AMERICAN STUDIES 21

\section{Chilean Rural Society from the Spanish Conquest to 1930 \\ ARNOLD J. BAUER}

This book attempts to place in historical perspective the evolution of Chilcan rural society from its foundation in the sixteenth century to the present day, and especially to explain the unusual result of accelerated economic growth after 1860 .

£8.60 net

\section{CAMBRIDGE UNIVERSITY PRESS}




\title{
LATIN AMERICAN FOREIGN POLICIES
}

\author{
An Analysis \\ Harold Eugene Davis, Larman C. Wilson \\ and others
}

Although Latin American international and foreign policy has been studied in the United States since the 1920s, this is the first book to present the subject from the perspective of the individual Latin American nations. It examines Latin American foreign policy country-by-country (or in a few cases, by small groups of countries), focusing on the formulation of foreign policy and how it is influenced by historical tradition and national politics. Each essay also analyzes the major international problems the countries confront and the position they assume in their relations with various other countries, regions, and international organizations.

From institutions around the country, the authors represent the points of view of a new generation of scholars. As historians, political scientists and economists, they provide interdisciplinary and theoretical diversity.

A challenging departure from the standard works in the field, this book makes a timely contribution to the study of Latin American foreign policy.

496 pages Cloth $£ 9.90$; Paper $£ 3.00$

\section{FROM COLONY TO NATION \\ Essays on the Independence of Brazil edited by A. J. R. Russell-Wood}

This is the first collection of essays to consider the fifty-year period preceding Brazilian independence in 1822 from cultural, political, economic, and social perspectives. The contributors, distinguished scholars in Brazilian history, present an up-to-date assessment of the importance of Brazilian independence based on extensive research in the libraries and archives of Portugal and Brazil.

The eight essays deal with preconditions and possible precipitants of the move toward independence, emancipation from Portugal and the oreation of a Brazilian national consciousness, U.S. policy toward the new nation, the effects of rural and urban growth on the political process, and the ideological and intellectual background of the independence movement.

From Colony to Nation contributes to our understanding of those events occurring in Portuguese America before and after independence and to our knowledge of modern Brazil and her role in contemporary Latin America.

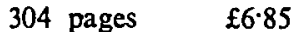

\section{Johns Hopkins University Press}

2-4 Brook Street, London W1 


\section{The Politics of Oil in Venezuela}

Franklin Tugwell. A case study of the relationship between foreign oil corporations and the state in Venezuela, this book focuses on the strategies adopted by Venezuelan leaders to control the behavior of the world's largest and most powerful multinational corporations. Among the main themes of the book are the pattern of bargaining and conflict between the government and the oil companies; the impact of ideology upon the selection of alternative courses of action; and the interdependence of the domestic political process, petroleum policy, and rapid social change. $\$ 8.95$

\section{Stanford University Press}

\section{BULLETIN OF HISPANIC STUDIES}

A QUARTERLY REVIEW

PUBLISHED BY THE

LIVERPOOL UNIVERSITY PRESS

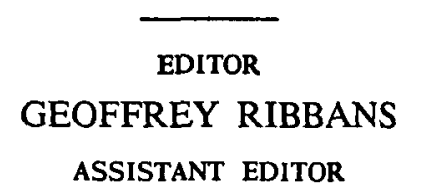

H. B. HALL

Editorial Committee: R. F. Brown, A. A. Parker, Frank Pierce, J. W. Rees, E. C. Riley, P. E. Russell, A. E. Sloman, W. Starkie, Arthur Terry, E. M. Wilson.

Editorial communications to the Editor, Bulletin of Hispanic Studies, The University, P.O. Box 147, Liverpool, L69 3BX.

Annual subscription, postage included: $£ 6.00, \$ 15.00$ or 900 pesetas. Write Bulletin of Hispanic Studies, Liverpool University Press, 123 Grove Street, Liverpool, L7 7AF. 


\section{FORO \\ INTERNACIONAL}

REVISTA TRIMESTRAL PUBLICADA POR EL COLEGIO DE MEXICO

Fundador: DANIEL COSIO VILLEGAS

Director: RAFAEL SEGOVIA

Director Adjunto: BLANCA TORRES RAMIREZ

Vol. XVI JULIO-SEPTIEMBre, 1975 NUM. 1

\section{N D I CE}

\section{ARTICULOS}

Donald Keesing, El financiamiento externo y los requerimientos de la modernización plena en México

Lorenzo Meyer, Continuidades e innovaciones en la vida política mexicana del siglo XX. El antiguo y el nuevo régimen

Atilio Boron, Notas sobre las raices histórico-estructurales de la movilización política en Chile

NOTA DE INVESTIGACION

RESEÑAS

LIBROS RECIBIDOS

Precio del ejemplar $\quad: 20.00$ pesos, U.S. Dls. 1.90

Suscripción anual (4 números) : 75.00 pesos, U.S. Dls. 6.50

\section{EL COLEGIO DE MEXICO}

Departamento de Publicaciones

Guanajuato 125

México 7, D.F. 


\section{REVISTA DEL CENTRO DE ESTUDIOS EDUCATIVOS}

VOLUMEN V, No. 2

SEGUNDO-TRIMESTRE DE 1975

DOCUMENTOS DE TRABAJO

Impacto de la sescuelos radiofónicas de América Latina en la educación: una perspectiva evaluativa

Emile G. McAnany.

A specto instrumental de la educación radiofónica: problemas de evaluación

Estela Barandiarán de Garland.

Objetivos de cambio conductual, actitudinal y valoral en la enseñanza radiofónica

Marcelino Llanos B.

Sugerencias para un diagnóstico sociológico para apoyar programas de educación radiofónica orientados al cambio social

Hugo Zemelman.

COMUNICACIONES

Sección abierta al diálogo o al debate sobre puntos de vista publicados en la Revista.

INFORMES, NOTAS Y DOCUMENTOS

Seminario sobre evaluación de sistemas de educación radiofónica. (Recomenda. ciones sobre prioridades de investigación y desarrollo de metodologias)

Osvaldo Kreimer.

Plan de estudios para un educator rural de adultos

ESTADISTICA

La enseñanza media en México, en 1973-1974

Isidoro del Camino y Jorge Muñoz Batista.

PRECIOS DE SUSCRIPCION

PARA MeXico: $\$ 150.00$ m.n. (120.00 para estudiantes y maestros).

Para Otros Paises, correo ordinario: 12 dls. (registrado y con acuse de recibo); correo aéreo: Centro y Sud América, 16 dls.; USA y Canadá, 19 U.S. dlls.; otros países, 22 dls. (registrado, con acuse de recibo y por entrega inmediata).

Suscripción y pedidos a:

REVISTA DEL CENTRO DE ESTUDIOS EDUCATIVOS

Av. Revolución 1291, México 20, D.F. Tel.: 593-92-04

Vol. VII, 2

\section{Cultures et développement}

\section{Revue internationale des sciences du développement}

\section{SO M M A I R E}

ARTICLES

Leo Goovaerts, L'Eglise et l'Etat au Zaïre à l'épreuve de l'«authenticité»).

Jacques LECLERC, La circonscription. Remarques sur l'idéologie du territoire national en Indonésie.

Ernst UTRECHT, The Javanese Dukun and his Role in Social Unrest.

Wilfred A. NDongko, Trade and Development Aspects of the Central African Customs and Economic Union.

\section{MELANGE}

James C. JACKSon, Economic Growth and the Problems of Peninsular Malaysia. A Review Article.

CHRONIQUE

F. Rodegem, Le Poker verbal. Réflexions sur un colloque.

\section{COURRIER}

John P. Powelson, About «What Went Wrong in Chile?».

\section{COMPTES RENDUS}

OUVRAGES ENVOYES A LA REDACTION.

BIBLIOGRAPHIE DES SCIENCES DU DEVELOPPEMENT.

\section{TARIFS D'ABONNEMENT}

4 numéros par volume. 1 volume par an. Belgique: F.B. 600 . Etranger F.B. 650 ou l'équivalent en monnaie du pays. A payer par virement ou chèque bancaire à la Société Générale de Banque à Leuven (C.C.P. 9.82), pour le compte No. 230-0048.119-27 de "Cultures et développement".

\section{A D R E S S E}

62 Tervuurse Vest, 3000 LEUVEN (Belgique). Tél. (016) 333.32. 


\section{NOTES FOR CONTRIBUTORS}

Journal of Latin American Studies is published twice a year under the academic sponsorship of the Centres or Institutes of Latin American Studies at the Universities of Cambridge, Glasgow, Liverpool, London and Oxford.

The scope of the journal is the study of Latin America from the standpoint of the social sciences, including anthropology, archaeology, economics, geography, history, international relations, politics, sociology, etc., though it is not concerned with linguistic or literary studies.

Editorial policy avoids commitment to any political viewpoint or ideology, but welcomes free discussion of such issues in the Latin American context, on the understanding that all responsibility for opinions expressed rests exclusively with the author concerned and not with either the journal or its editors.

Contributions are invited from all parts of the world. Articles should generally not be more than 8,000 words long, and two copies, typed with double-spacing, should be submitted. Diagrams and maps may be included by arrangement with the editors. The journal is published in English, but articles written in other languages may be considered, and arrangements made as required for translation into English. Contributors should keep one copy of the typescript for use in correcting proofs.

All contributions and editorial correspondence should be addressed to Journal of Latin American Studies, Institute of Latin American Studies, 3I Tavistock Square, London, WCiH $9 \mathrm{HA}$.

Each contributor will receive, free of charge, 25 offprints of his article and a copy of the issue of the journal in which it appears.

\section{CONTRIBUTORS TO THIS ISSUE}

Dr Herbert S. Klein is Professor of History at Columbia University, New York. Dr Timothy E. Anna is Assistant Professor of History at the University of Manitoba.

DR F. W. O. Morton is Assistant Professor of History at the University of Calgary.

Dr Frederick M. Nunn is Associate Professor of History at Portland State University.

DR D. A. EASTwOod is Lecturer in Geography at the New University of Ulster, Coleraine. 
J. Lat. Amer. Stud.

\section{Journal of \\ Latin American Studies}

Volume 7 Part 2 November 1975

\section{A R T I CLES}

Herbert S. Klein: Hacienda and Free Community in Eighteenth-

Century Alto Peru: A Demographic Study of the Aymara Population of the Districts of Chulumani and Pacajes in 1786

$193-220$

Timothy E. Anna: The Peruvian Declaration of Independence:

Freedom by Coercion

F. W. O. Morton: The Military and Society in Bahia, $1800-182 \mathrm{I}$

Frederick M. Nunn: New Thoughts on Military Intervention in Latin American Politics: The Chilean Case, 1973

D. A. EAstwoon: Observations on the Relationship between Intrarural Migration and Achievement Motivation in Mérida State, Venezuela

\section{REVIEWS by}

D. B. Quinn, 329-330; Rory Miller, 330-331; Peter Calvert, 331-332; D. L. Raby, 332-333; David Rock, 333-336; Lynn Darrell Bender, 336337; Ken Medhurst, 337-338; Alan Gilbert, 338-340; Alan Angell, 340-342; Peter Rivière, 342-343; Warwick Bray, 344; Edy Kautman, 345-346; C. R. Boxer, 346-348; Francis Lambert, 348-350.

(C) Cambridge University Press 1975.

CAMBRIDGE UNIVERSITY PRESS

Bentley House, 200 Euston Road, London NW1 2 DB

32 East 57 th Street, New York, N.Y. 10022

Printed in Great Britain by The Eastern Press Ltd., London and Reading 